\title{
Fungal neonatal and infantile sepsis in Egypt: risk factors and identification of fungal isolates
}

\author{
${ }^{1 *}$ Ahmed, S. H., ${ }^{2}$ Mokhtar, E. M., ${ }^{3}$ El-Kholy, I. M., ${ }^{4}$ El Essawy, A. K., ${ }^{1}$ El-Din, A. A., \\ and ${ }^{1}$ Shetaia, Y. M. \\ ${ }^{1}$ Microbiology Department, Faculty of Science, Ain Shams University, Cairo, Egypt \\ ${ }^{2}$ Microbiology Department, Abou Al-azayem Hospital, Cairo, Egypt \\ ${ }^{3}$ Clinical Pathology Department, Ain Shams University Specialized Hospital, Ain Shams University, Cairo, Egypt \\ ${ }^{4}$ Microbiology Department, Ain Shams University Specialized Hospital, Ain Shams University Cairo, Egypt, \\ *Correspondence to: sara_saifelnasr@hotmail.com; 00971563993304
}

\begin{abstract}
:
Background: Invasive fungal diseases (IFDs) are opportunistic infections associated with significant mortality in paediatric patients, especially in those with compromised immune system and neonates with very low birth weight (VLBW). The objectives of this study are to determine the prevalence, clinical features and fungi isolates of neonatal sepsis in three hospitals in Egypt.

Methodology: The study is a cross sectional survey of 176 neonates with clinical sepsis admitted to the neonatal intensive care units (NICU) of the three hospitals over a period of one year (February 2015 to January 2016). A minimum of two blood samples (collected within 24 hours) from each neonate were cultured for bacteria in automated BacT/AlerT and conventional culture bottles, while Saboraud-Brain Heart Infusion broth was inoculated for fungi culture. Positive growths from the broth were sub-cultured on Sabouraud Dextrose Agar (SDA) plates for aerobic incubation at $25^{\circ} \mathrm{C}$ and $37^{\circ} \mathrm{C}$ for 2 weeks. Identification of fungi colonies on SDA was by conventional morphology and confirmation on chromogenic agar media. Phylogenetic analysis of representative fungi isolates was done by partial nucleotide sequencing of D1-D2 domain of the large subunit rRNA gene.

Results: Of the 176 neonates, blood culture was positive for pathogens in $55(31.3 \%)$ samples and fungi were isolated in $26(14.8 \%)$; yeast (25) and mould (1). The commonly isolated yeasts were Candida albicans, Candida tropicalis, and Candida krusei representing 34.6\%, 30.8\% and $23.1 \%$, respectively of the total fungi isolated. The phylogenetic analysis in comparison to Genbank data showed defined clades for Candida tropicalis, Candida parapsilosis, Candida albicans and Pichia kudriavzevii

Conclusion: This current study highlights the changing pattern of neonatal infections in Egypt caused by Candida, with increasing incidence of infections caused by non-albicans Candida species.
\end{abstract}

Key words: fungal infection, neonatal, risk factors, PCR, yeast

Received July 4, 2019; Revised September 16, 2019; Accepted September 18, 2019

Copyright 2020 AJCEM Open Access. This article is licensed and distributed under the terms of the Creative Commons Attrition 4.0 International License (http://creativecommmons.org/licenses/by/4.0), which permits unrestricted use, distribution and reproduction in any medium, provided credit is given to the original author(s) and the source.

\section{Infection fongique néonatale et infantile en Égypte: facteurs de risque et identification des isolats fongiques}

\author{
${ }^{1 *}$ Ahmed, S. H., ${ }^{2}$ Mokhtar, E. M., ${ }^{3}$ El-Kholy, I. M., ${ }^{4}$ El Essawy, A. K., ${ }^{1}$ El-Din, A. A., \\ et ${ }^{1}$ Shetaia, Y. M. \\ ${ }^{1}$ Département de microbiologie, Faculté des sciences, Université Ain Shams, Le Caire, Égypte \\ ${ }^{2}$ Département de microbiologie, Hôpital Abou Al-Azayem, Le Caire, Égypte \\ ${ }^{3}$ Département de pathologie clinique, Hôpital spécialisé de l'Université Ain Shams, Université Ain Shams, \\ Le Caire, Égypte \\ ${ }^{4}$ Département de microbiologie, Université de Ain Shams, Spécialisé Hôpital, Université Ain Shams, \\ Le Caire, Égypte \\ *Correspondance à: sara saifelnasr@hotmail.com; 00971563993304
}

\section{Abstrait:}

Contexte: Les maladies fongiques invasives (IFD) sont des infections opportunistes associées à une mortalité significative chez les patients pédiatriques, en particulier ceux dont le système immunitaire est compromis et les nouveau-nés de très faible poids à la naissance (VLBW). Les objectifs de cette étude sont de déterminer la 
prévalence, les caractéristiques cliniques et les isolements fongiques de la sepsie néonatale dans trois hôpitaux en Égypte.

Méthodologie: L'étude est une enquête transversale menée auprès de 176 nouveau-nés présentant une septicémie clinique et admis dans les unités de soins intensifs néonatals des trois hôpitaux sur une période d'un an (de février 2015 à janvier 2016). Un minimum de deux échantillons de sang (recueillis dans les 24 heures) de chaque nouveau-né ont été cultivés pour la bactérie dans des flacons de culture automatisés BacT/AlerT et conventionnels, tandis que le bouillon Saboraud-Brain Heart Infusion a été inoculé pour la culture de champignons. Les croissances positives du bouillon ont été sous-cultivées sur des plaques de gélose Sabouraud Dextrose Agar (SDA) pour une incubation aérobie à $25^{\circ} \mathrm{C}$ et à $37^{\circ} \mathrm{C}$ pendant 2 semaines. L'identification des colonies de champignons sur la SDA a été réalisée par la morphologie conventionnelle et confirmée sur un milieu chromogène en gélose. L'analyse phylogénétique d'isolats de champignons représentatifs a été réalisée par séquençage partiel de nucléotides du domaine D1-D2 du gène de I'ARNr de grande sous-unité.

Résultats: Sur les 176 nouveau-nés, la culture de sang était positive pour les agents pathogènes dans 55 échantillons $(31,3 \%)$ et les champignons ont été isolés dans $26(14,8 \%)$; levure (25) et moisissure (1). Les levures communément isolées étaient Candida albicans, Candida tropicalis et Candida krusei, représentant respectivement $34,6 \%, 30,8 \%$ et $23,1 \%$ du total des champignons isolés. L'analyse phylogénétique comparée aux données de Genbank a montré des clades définis pour Candida tropicalis, Candida parapsilosis, Candida albicans et Pichia kudriavzevii

Conclusion: La présente étude met en évidence l'évolution du schéma des infections néonatales causées par Candida en Égypte, avec une incidence croissante des infections causées par des espèces de Candida non albicans.

Mots-clés: infection fongique, néonatale, facteurs de risque, PCR, levure

\section{Introduction:}

Generally, neonatal infections continue to be an important cause of morbidity and mortality worldwide. This is due to lack of adequate preventive and therapeutic strategies in low income settings and increased survival of preterm and low weight newborns with lengthy stays in intensive care units (NICUs) in high income countries (1).

Neonatal sepsis refers to infection in newborn less than 28 days old with presence of microorganisms (bacteria or fungi) in the blood stream in the setting of fever. Preterm babies are more commonly affected than term babies (2). Two types of neonatal sepsis can be defined according to time and mode of infection; early onset sepsis (EOS) results from maternal intrapartum transmission of invasive organisms and can be diagnosed when there is positive microbial cultures during the first 7 days of life or during the first 72 hours of life in case of very low birth weight (VLBW) infants (3). Late-onset sepsis (LOS) referred to infection in blood and cerebrospinal fluid occurring after 7 days of delivery, which occurs from postnatal acquisition (nosocomial or community sources) of pathogens (4).

It has been reported that the incidence of sepsis during the neonatal period is higher than any other period of life and varies from one place to another (5), and from nursery to nursery depending on predisposing factors to infections $(6,7)$. Several predisposing factors for fungal infections have been identified, some of which are related to host factor and others to prolonged hospitalization. Innate characteristics of preterm infants that predispose them to invasive fungal infections include relative immunodeficiency resulting from decreased number of T-cells and neutrophils, immature skin structure, disruption of cutaneous barriers, prolonged use of antimicrobials, indwelling central venous catheters, hyper alimentation, incubation, steroids and other uncommon risk factors (8).

Candida species are important hospital acquired pathogens in infants admitted to the neonatal intensive care units (NICU). In VLBW infants (birth weight less than $1500 \mathrm{~g}$ ), Candida albicans is the third most common cause of neonatal LOS, which occurs after the first 72 hours of life (9). Candida albicans represents $60 \%$ of neonatal fungi infections $(10,11)$ but non-albicans Candida species are also associated with neonatal infections and includes Candida tropicalis, Candida parapsilosis, Candida krusi and Candida glabrata, which are considered emerging pathogens (12).

The symptoms and signs of neonatal sepsis are subtle and overlap with other life threatening infectious diseases, thereby making early diagnosis difficult $(13,14)$. Blood culture remains the gold standard for definitive diagnosis of neonatal sepsis (15). Mortality from invasive candidiasis (IC) is influenced by variables such as drugs, timing, and duration of treatment. Prompt treatment and appropriate dosing for neonatal IC are important strategies to halt progression of disease. The objectives of this study are to determine the prevalence of fungal neonatal sepsis, characterize the aetiological agents and compare the pattern with that of our previous study conducted over a decade ago. 


\section{Materials and method:}

\section{Study design and setting}

This was a cross sectional study conducted in neonatal intensive care units (NICUs) of three Egyptian hospitals; Al-Azhar University Hospital, Ain-Shams University Hospital and Wadi El-Neel Hospital, between February 2015 and January 2016.

\section{Subjects}

A total of 176 neonates and infants less than 6 months of age with clinical sepsis admitted to the hospitals during the period of study were recruited for the study. Full clinical history and physical examination were conducted on each subject and data such as gestational age, birth weight, mode of delivery, and risk factors for sepsis were collected into a design form.

\section{Specimen culture and microbial isolation}

A minimum of two blood samples (collected within 24 hours) from each neonate were inoculated into BacT/Alert bottles for incubation in automated bacteria BacT/Alert blood culture machine (BioMérieux France) or into Thioglycollate broths for conventional aerobic and anaerobic bacteria incubation for 14 days. For fungi isolation, blood samples were inoculated into Saboraud-Brain Heart Infusion broth and positive growth sub-cultured on Saboraud Dextrose Agar (SDA) plates for aerobic incubation at $25^{\circ} \mathrm{C}$ and $37^{\circ} \mathrm{C}$ for two weeks.

\section{Biochemical identification of fungi isolates}

For mould, identification was carried out on the basis of macroscopic and microscopic morphology using the universal mycology manual (16). Identification of yeast species was carried out according to macroscopic characteristics on Wickerham agar medium, color production on chromogenic agar media (Sigma Chemicals, USA), germ tube test, chlamydospores formation, and carbohydrates fermentation and assimilation (17).

\section{Partial sequencing and phylogenetic analysis of fungi isolates}

DNA was extracted using the protocol of GeneJET $^{\text {TM }}$ genomic DNA purification kit (Thermo \#k0721). PCR was carried out using Maxima Hot Start PCR Master Mix (Thermo, \#k1061) with amplification of the divergent domain at the $5^{\prime}$ end of the large subunit (LSU) rRNA gene using primers; NL-1 (5'GCATATCAATAAGCGGAGGAAAAG-3') and NL4 (5'-GGTCCGTGTTTCAAGACGG-3'). The PCR conditions set were 35 cycles of initial denaturation at $94^{\circ} \mathrm{C}$ for $3 \mathrm{~min}$ followed by denaturation at $94^{\circ} \mathrm{C}$ for $1 \mathrm{~min}$, annealing at $50^{\circ} \mathrm{C}$ for $2 \mathrm{~min}$, and extension at $74^{\circ} \mathrm{C}$ for
$1.5 \mathrm{~min}$, with a final extension at $74^{\circ} \mathrm{C}$ for 5 min. The PCR product was purified using GeneJET ${ }^{\mathrm{TM}}$ PCR purification Kit (Thermo, $\mathrm{k} 0701)$, and stored at $-20^{\circ} \mathrm{C}$ prior to sequencing.

The PCR products of five representative isolates were sequenced on GATC Company using ABI 3730xI DNA sequencer with the forward and reverse primers that target the D1-D2 domain of the large subunit rRNA gene. The forward and reverse DNA sequence reads for each isolate were assembled using codon code aligner software and submitted to Genbank with assigned accession numbers.

A phylogram was constructed for the 5 clinical isolates and their closely related strains according to Genbank data based on nucleotide divergence in the D1-D2 domain. The evolutionary history was inferred using the Neighbor-Joining method (18), and the percentage of replicate trees in which the associated taxa clustered together in the bootstrap test (100 replicates) was shown next to the branches (19). The tree was drawn to scale with branch lengths in the same units as those of the evolutionary distances used to infer the phylogenetic tree.

The evolutionary distances were computed using the number of differences method (20) and were in the units of the number of base differences per sequence. The analysis involved 56 nucleotide sequences. All ambiguous positions were removed for each sequence pair (pairwise deletion option). There were a total of 594 positions in the final dataset. Evolutionary analyses were conducted in MEGA $X$ software (21).

\section{Statistical analysis}

Data were analyzed using the Statistical Package for the Social Sciences (SPSS) version 20.0. Quantitative data were expressed as mean \pm standard deviation (SD) while qualitative data were expressed as frequency and percentages. The Chisquare $\left(X^{2}\right)$ test was used to compare proportions between two qualitative parameters. The confidence interval was set to $95 \%$ and the accepted margin of error was set to $5 \%$. The significance of probability ( $p$ value) was evaluated as follow; $p<0.05$ was considered significant, $p<0.001$ was considered highly significant, and $p>0.05$ was considered not significant.

\section{Ethical issues}

The ethical committees of the participating hospitals approved the study. All patients' information and test results were kept confidential. 


\section{Results:}

A total of 176 neonates and infants less than 6 months old with clinical sepsis were enrolled, 97 males and 79 females (M: $F$ ratio of 1.2). The age range of subjects is 1-210 days with mean age of 39.7 days (Table 1). Blood culture was positive for pathogens in 55 subjects $(31.3 \%)$ and for fungi in $26(14.7 \%)$, with $21.5 \%$ in females, which was significantly higher than $9.3 \%$ in males $(p=0.0391)$.

Twenty one (18.4\%) of the 114 early onset cases had fungi isolated compared to 5 of $62(8.1 \%)$ late onset cases but there was no significant difference between the two cases $(p=0.1037)$. Twenty three of 136 $(16.9 \%)$ LBW babies had fungi sepsis compared to 3 of 40 (7.5\%) NBW babies but the difference was not significant $(p=0.220)$. Nine of $87(10.3 \%)$ babies who had normal vaginal birth had fungi sepsis while 17 of 89
(19.1\%) babies with cesarean section (CS) birth had fungi sepsis but no significant difference was observed ( $p=0.1543)$.

The frequency of isolation of the fungi species is shown in Table 2 with 24 isolates being Candida species, one isolate was Pichia (yeast) and one isolate was a mould (Penicillium). Out of the 24 Candida species, non-albicans species accounted for $15(62.5 \%)$. However the most frequent species in descending order were $C$. albicans $(n=9,34.6 \%), C$. tropicalis $(n=8,30.8 \%)$ and C. krusei $(\mathrm{n}=6,23.1 \%)$.

The Phylogenetic tree (Fig 1) shows selected 5 pathogenic yeast isolates and their closely related strains according to Genbank data. The phylogenetic tree showed defined clades for C. tropicalis (isolate 3, MK686027 and isolate 5, MK686029), C. parapsilosis (isolate 4, MK686028), C. albicans (isolate 2, MK686026), and P. kudriavzevii (isolate 1 , MK686025).

Table 1: Demographic data and of risk factors for fungi sepsis among neonates and infants in Egypt

\begin{tabular}{|c|c|c|c|c|c|}
\hline $\begin{array}{l}\text { Demographic data } \\
\text { and risk factors }\end{array}$ & $\begin{array}{l}\text { No of subjects }(\%) \\
\qquad(n=176)\end{array}$ & $\begin{array}{l}\text { No of subjects with } \\
\text { fungi isolates }(\%) \\
(n=26)\end{array}$ & $x^{2}$ & $95 \% \mathrm{CI}$ & $p$ value \\
\hline \multicolumn{6}{|l|}{ Gender } \\
\hline Male & $97(55.1)$ & $9(9.3)$ & 4.255 & $0.2034-0.9142$ & $0.0391 *$ \\
\hline Female & $79(44.9)$ & $17(21.5)$ & & & \\
\hline \multicolumn{6}{|l|}{ Age (days) } \\
\hline Mean \pm SD & 39.7 & & & & \\
\hline Range & $1-210$ & & & & \\
\hline \multicolumn{6}{|l|}{ Weight (gm) } \\
\hline LBW $(<2500)$ & $136(77.3)$ & $23(16.9)$ & 1.491 & $0.7136-7.126$ & 0.2220 \\
\hline NBW $(\geq 2500)$ & $40(22.7)$ & $3(7.5)$ & & & \\
\hline \multicolumn{6}{|l|}{ Sepsis onset } \\
\hline EOS & $114(67.8)$ & $21(18.4)$ & 2.648 & $0.9056-5.762$ & 0.1037 \\
\hline LOS & $62(35.3)$ & $5(8.1)$ & & & \\
\hline \multicolumn{6}{|l|}{ Mode of delivery } \\
\hline NVD & $87(49.4)$ & $9(10.3)$ & 2.029 & $0.2553-1.149$ & 0.1543 \\
\hline $\mathrm{CS}$ & $89(50.6)$ & $17(19.1)$ & & & \\
\hline
\end{tabular}

Table 2: Frequency of isolated fungi in neonates and infants with sepsis in Egypt

\begin{tabular}{ccc}
\hline Fungi pathogen & Frequency of isolation & Percentage \\
\hline Candida albicans & 9 & 34.6 \\
Candida tropicalis & 8 & 30.7 \\
Candida krusei & 6 & 23.1 \\
Candida parapsilosis & 1 & 3.8 \\
Pichia kudriavzevii & 1 & 3.8 \\
Penicillium oxalicum & 1 & 3.8 \\
Total & 26 & 100 \\
\hline
\end{tabular}




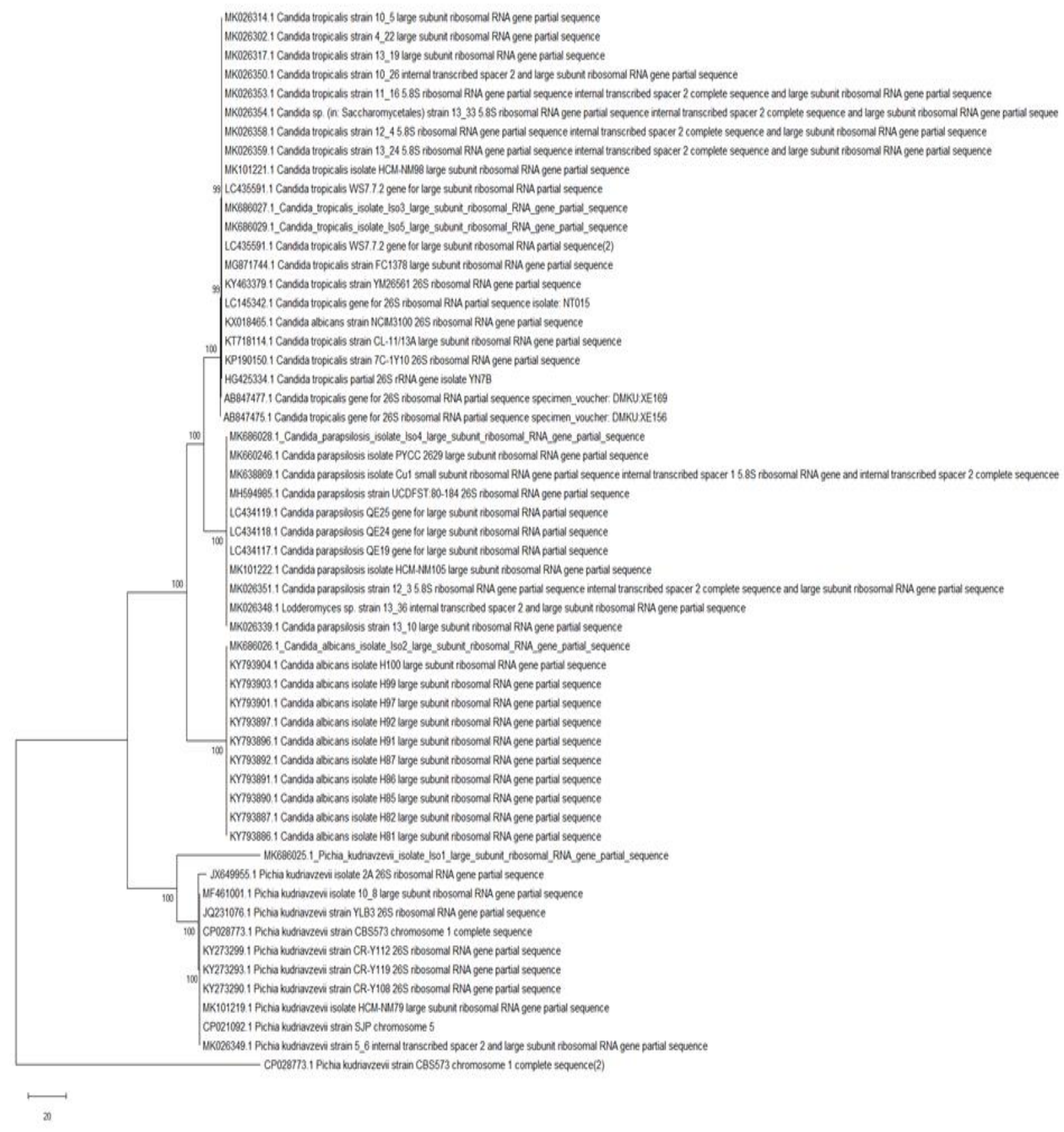

Fig 1: Phylogenetic tree of the pathogenic yeast isolates and closely related strains according to Genbank data

\section{Discussion:}

Invasive candidiasis is an emerging cause of LOS, especially among infants who receive broad-spectrum antimicrobial agents (22). Globally, neonatal sepsis is still one of the major causes of morbidity and mortality in spite of recent advances in health care (23). Differing estimates of disease burden have been reported from high-income countries compared with reports from lowand-middle-income countries (24). More than $40 \%$ of under-five deaths globally occur in the neonatal period resulting in 3.1 million newborn deaths each year (25). The majority of these deaths usually occur in low income countries and almost 1 million of these deaths are attributed to infectious causes including neonatal sepsis, meningitis and pneumonia (26). The prevalence of fungal 
sepsis in neonates admitted in NICU, ranges from 2.6 to $16.7 \%$ (27).

In the present study, the prevalence of $14.7 \%$ for fungal sepsis is similar to the rates of $11 \%, 13.6 \%, 13.9 \%$ and $11.97 \%$ reported by Rani et al., (28), Agarwal et al., (29), Chen et al., (30) and Chavhan et al., (27) respectively. In a previous study by Mokhtar et al., (11), the rate of fungal neonatal sepsis reported was $12 \%$ of the total diagnosed cases while bacterial sepsis represented $88 \%$, but in the current study, fungal sepsis has increased to $14.7 \%$. Advances in neonatal management have led to considerable improvement in newborn survival (31)

The results in this study showed that candidal sepsis commonly occurred in low weight and preterm neonates, similar results were reported in other studies by Schellack and Gous (32), Femitha and Joy (33), Kapila (34), and Koppad and Prakash (35). Low weight and preterm are risk factors for fungal sepsis because of immaturity of their immune system and invasive intervention. Candida species has become the third most common cause of late onset sepsis in NICU with mortality figures varying between 15 to $59 \%$ (36).

The present study shows the changing pattern of candidal species (from the last decade) among neonatal fungal sepsis with increasing prevalence of nonalbicans Candida species which in this study constituted $62.5 \%$ of the 24 Candida isolates. These findings are consistent with other recent studies by Kapila (34), Koppad (35) and Chavhan (27) which reported prevalence rates of $86.4 \%, 71 \%$ and $65 \%$ respectively, for non-albicans Candida species. Although initial reports indicated that most cases were due to $C$. albicans, more recent studies showed the emergence of the non-albicans C. parapsilosis, by $54 \%$ and $30 \%$ in the study by Ballot et al., (37) and $30 \%$ in another study by Chavhan et al., (27).

\section{Acknowledgements:}

The authors appreciate Prof. Dr. Alzahraa Karam Eldin, Ain Shams University, for her assistance

\section{Sources of fund:}

No fund was received for the study

\section{Conflict of interest:}

No conflict of interest is declared

\section{References:}

1. Cortese, F., Scicchitano, P., Gesualdo, M., et al. Early and Late Infections in Newborns: Where Do We Stand? A Review, Pediatrics and Neonatology. $2016: 57,265-273$

2. Wynn, J. L. Defining neonatal sepsis. Curr Opin Pediatr. 2016; 28 (2): 135-140.

3. Mukhopadhyay, S., and Puopolo, K. M. Risk Assessment in Neonatal Early-Onset Sepsis, Semin Perinatol. 2012;

4. Camacho-Gonzalez, A., Spearman, P. W., and Stoll, B. J. Neonatal infectious diseases: evaluation of neonatal sepsis. Pediatr Clin North Am. 2013: 60 (2): 367-389.

5. Thaver, D., and Zaidi, A. K. M. Burden of Neonatal Infections in Developing Countries, A Review of Evidence From Community-Based Studies. Pediatr Infect Dis J. 2009; 28: 1.

6. Jumah, D. S., and Hassan, M. K. Predictor of mortality outcome in neonatal sepsis. Med J Basrah University. 2007: 25 (1):

7. Klein, $\mathrm{O}$, and Remington, J. S. Current concepts of infection of the fetus and newborn infant. In: Remington J., and Klein, J. (eds). Infectious Diseases of the Fetus and Newborn. W B Saunders, Philadelphia, Pa, USA, 2000: 1 - 24

8. Manzoni, P., Mostert, M., and Castagnola, E. Update on the management of Candida infections in preterm Neonates. BMJ. 2014

9. Dessì, A. Neonatal fungal infections new strategies in diagnosis: J Pediatr Neonatal Individualized Med. 2014; 3 (2): e030222.

10. Kaufman, D. A. Fungal Infections in Preterm Infants: Medscape, 2014.

11. Mokhtar, E., El-Shereef, A., Abdel-Kader, A., et al. Early Diagnosis of Neonatal Sepsis Caused by Yeast Infection, Austin J Publ HIth Epidemiol. 2014; 1 (2):

12. Pfaller, M. A., Pappas, G. P., and Wingard, J. R. Invasive Fungal Pathogens: Current Epidemiological Trends. Clin Infect Dis. 2006;

13. English, M., Ngama, M., Mwalekwa, L., et al. Signs of illness in Kenyan infants aged less than 60 days, Bulletin of the World Health Organization, 2004; 82 (5): 323-329.

14. Young Infants Clinical Signs Study Group: Clinical signs that predict severe illness in children under age 2 months: a multicentre study, Lancet. 2008

15. Utomo, M. T. Risk factors of neonatal sepsis: a preliminary study in Dr. Soetomo hospital. Indonesian J Trop Infect Dis, 2010; 1: 23-26

16. De Hoog, G. S. Atlas of Clinical Fungi, Second Edition, Amer Society for Microbiology. $2000: 1$ 1126

17. Lodder, J. The Yeasts: a taxonomic study, North-Holland Publishing Company, Amsterdam, second edition. 2000.

18. Saitou, N., and Nei, M. The neighbor-joining method: A new method for reconstructing phylogenetic trees. Molecular Biology and Evolution. 1987; 4: 406-425.

19. Felsenstein, J. Confidence limits on phylogenies: An approach using the bootstrap. Evolution. 1985. 39: 783-791.

20. Nei, M., and Kumar, S. Molecular Evolution and Phylogenetics. Oxford University Press, New York, 2000.

21. Kumar, S., Stecher, G., Li, M., et al. MEGA X: Molecular Evolutionary Genetics Analysis across computing platforms. Molecular Biology and Evolution. 2018, 35: 1547-1549.

22. Shane, A.L., Stoll, B. J. Recent Developments and Current Issues in the Epidemiology, Diagnosis, and Management of Bacterial and Fungal Neonatal Sepsis, Am J Perinatol. 2013; 30 (02): 131-142 
23. Wu, J. H., Chen, C. Y., Tsao, P. N., et al. Neonatal sepsis: a 6-year analysis in a neonatal care unit in Taiwan. Pediatrics and Neonatology, 2009; 50 (3): 88-95

24. Shane, A. L., Sánchez, P. J., and Stoll, B. J. Neonatal sepsis. Lancet. 2017; 390 (10104): $1770-1780$.

25. UNICEF, WHO, The World Bank, and The United Nations, Levels and Trends in Child Mortality, UNICEF, New York, NY, USA, 2011

26. Black, R. E., Cousens, S., Johnson, H. L., et al Global, regional, and national causes of child mortality in 2008: a systematic analysis. Lancet, 2010; 375 (9730): 1969 - 1987.

27. Chavhan, S. K., Meena, J. S., Meena, K. K., and Meena, K. J. Candidemia in Neonatal Intensive Care Units: Magnitude, Species Identification And Antifungal Susceptibility Pattern, IOSR Journal of Dental and Medical Sciences. 2017; 16 (6):

28. Rani, R Mohapatra, N. P Mehta, G, et al. Changing trends of Candida species in neonatal septicaemia in a tertiary North Indian hospital. Indian J Med Microbiol. 2002

29. Agarwal, J., Bansal, S., Malik, G. K., and Jain, A. Trends in neonatal septicaemia: Emergence of non-albicans Candida. Indian Pediatr. 2004; 41: 712-715

30. Chen, J., Jiang, Y., Wei, B., et al. Epidemiology of and risk factors for neonatal candidaemia at a tertiary care hospital in western China. BMC Infect Dis. 2016; 16: 700 .
31. Kumar, A., Yadav, A., Gathwala, G., et al. Study of risk factors for candida species colonisation of neonatal intensive care unit patient. Int J Pharma and Biosci. 2012; 3 (2): 193-199

32. Schellack, N., and Gous, A. G. S. Amphotericin $B$ in the management of fungal infections in a neonatal intensive care unit: experiences in a teaching hospital. South Afr J Epidemiol Infect. 2012;

33. Femitha, P., and Joy, R. Candidaemia in neonatal ICU-experience from a tertiary care hospital. Curr Pediatr Res. 2013; 17 (1): 44-48

34. Kapila, S., Goel, S. P., and Prakash, A. Identification of Candida species in neonatal septicemia. Int J Contemp Pediatr. 2016; 3(2): 601-605

35. Koppad, B., and Prakash, K. P. Neonatal candidiasis: clinical spectrum and epidemiology in a tertiary care centre, Int J Contemp Pediatr. 2017; 4 (2): 438-441

36. Montagna, M. T. Lovero, G. De Giglio, O., et al. Invasive fungal infections in neonatal intensive care units of Southern Italy: a multicentric regional active surveillance. J Prev Med Hyg. 2010; 51 (3): 125-

37. Ballot, D. E., Bosman, N., Nana, T., et al. Background changing patterns of neonatal fungal sepsis in a developing country. J Trop Pediatr. 2013; 59 (6): 460-464 